\title{
PERILAKU MEROKOK SISWA SEKOLAH DASAR (SD) KECAMATAN KAMPAR KIRI KABUPATEN KAMPAR
}

\author{
Nofri Hasrianto $^{1}$, Nurvi Susanti ${ }^{2}$, Asrizal $^{3}$ \\ S1 Kesehatan Masyarakat ${ }^{1}$, S1 Kesehatan Masyarakat ${ }^{2,3}$ \\ STIKes Al Insyirah Pekanbaru ${ }^{1}$, STIKes Hang Tuah Pekanbaru ${ }^{2,3}$ \\ nofrihasrianto@gmail.com ${ }^{1}$, nurvisusanti83@gmail.com ${ }^{2}$
}

\begin{abstract}
Riau province, second largest cigarette smoker, 24.2\% per day, the second largest average number of cigarettes smoked in Riau in 2013 was in Kampar Regency Sebayak (17.8\%), (Riskesdas, 2013). Based on the initial survey, observation and interviews with SD 004 Domo students, on 15 male students, 9 of whom had smoked. The aim of this study was to determine factors related to smoking behavior in students of SDN Kampar Kiri District, Kampar Regency. This research is a quantitative analysis with a transversal conception. The male student population was 100 respondents, consisting of 3 elementary schools in Kampar Kiri district, Kampar Regency, namely SDN 004 Domo Village, SD 002 Kuntu and SD 011 Kuntu. Questionnaire measurement tool. The sampling technique in this study is to use the total sampling technique with criteria. Data analysis Univariate and bivariate analysis with the chi-square test. The results of the study show a relationship between knowledge $(P$ value $=0.017<\alpha 0.05$ with POR 4.023), attitude ( $p$-value $=0.000<\alpha 0.05$ with POR 15750), cigarette advertising (Pvalue $=0.039<\alpha 0.05$ with POR 4.259), smoking friends $(P$-value $=0.000<\alpha 0.05$ with POR 6465), smoker families ( $P$-value $0.000<\alpha 0.05$ with POR 6.465), pocket money $(P$-value $=0.000$ $<\alpha 0.05$ with POR 13333) on the smoking behavior of pupils District SD Kampar Kiri, regency of Kampar. There are 6 variables related to smoking behavior among SD students of Kampar Kiri subdistrict, Kampar regency, namely knowledge, attitudes, cigarette advertisements, peers, families of smokers and l'pocket money.
\end{abstract}

Key Words: Attitude, Knowledge, Smoker Friends, Smoker's Family

\begin{abstract}
ABSTRAK
Provinsi Riau, penghisap rokok kedua terbayak, setiap hari 24,2\%, jumlah rerata batang rokok yang di hisap tertinggi kedua di Riau tahun 2013 terdapat di Kabupaten Kampar sebayak (17,8\%), (Riskesdas, 2013). Berdasarkan surve awal, observasi dan wawancara pada siswa di SD 004 Domo dari 15 orang siswa laki laki 9 di antaranya perna merokok. Tujuan penelitian ini untuk mengetahui faktor yang berhubungan dengan perilaku merokok pada siswa di SDN Kecamatan Kampar Kiri Kabupaten Kampar. Penelitian ini bersifat Analitik kuantitatif dengan desain Cross Sectional. Populasi siswa laki-laki sebanyak 100 responden, yang terdiri dari 3 SD di Kecamatan Kampar Kiri Kabupaten Kampar yaitu SDN 004 Desa Domo, SD 002 Kuntu dan SD 011 Kuntu. Alat ukur kuesioner. Teknik pengambilan sampel pada penelitian ini ialah mengunakan teknik Total Sampling dengan kriteria. Analisis data Analisis Univariat dan Bivariat dengan uji chi square. Hasil Penelitian terdapat hubungan antara Pengetahuan ( $\mathrm{P}$ value $=0,017<\alpha 0.05$ dengan POR 4,023), Sikap (Pvalue $=0,000<\alpha 0.05$ dengan POR 15,750), Iklan Rokok (Pvalue $=0,039<\alpha 0.05$ dengan POR 4,259), Teman perokok ( $\mathrm{P}$ value $=0,000<\alpha 0.05$ dengan $\mathrm{POR} 6,465)$, Keluarga Perokok ( $\mathrm{P}$ value $0,000<\alpha 0.05$ dengan POR 6,465), Uang Jajan (P value $=0,000<\alpha 0.05$ dengan POR 13,333) terhadap perilaku merokok pada siswa SD Kecamatan Kampar Kiri Kabupaten Kampar. Terdapat 6 variabel yang berhubungan dengan perilaku merokok pada siswa SD Kecamatan Kampar Kiri Kabupaten Kampar yaitu Pengetahuan, Sikap, Iklan Rokok, Teman Sebaya, Keluarga Perokok dan Uang Jajan.
\end{abstract}

Kata Kunci: Pengetahuan, Sikap, Teman Perokok, Keluarga Perokok 


\section{PENDAHULUAN}

Merokok merupakan kegiatan yang selalu terlihat di masyarakat. Meskipun sebagian besar masyarakat mengetahui bahaya merokok, namun kebiasaan merokok tetap banyak dilakukan di masyarakat, karena papan iklan rokokpun menyampaikan halter sebut. Yang lebih menyedihkan dari kegiatan merokok adalah bahwa kebiasaan ini tidak hanya terjadi pada orang dewasa namun telah merambah ke remaja bahkan siswa sekolah (Wulandari,2017).

Rokok mengandung zat-zat yang dapat menyebabkan kanker. Didalam rokok terkandung zat adiktif, yaitu bahan yang penggunaannya dapat menyebabkan ketergantungan psikis. Asap rokok mengandung kurang lebih 4000 jenis senyawa kimia yang 200 jenis diantaranya adalah termasuk zat berbahaya dan 43 jenis lainnya dapat menyebabkan kanker bagi tubuh. Beberapa zat yang sangat berbahaya diantaranya yaitu Nikotin, Tar, dan Karbon Monoksida (Wulandari,2017)

Kebiasaan merokok sudah menjadi budaya pada bangsa Indonesia.Remaja, dewasa, bahkan anak-anak sudah tidakasing lagi dengan benda mematikan tersebut. Perilaku merokok yang dilakukan oleh remaja sering kita lihat di berbagai tempat, misalnya di warung dekat sekolah, perjalanan menuju sekolah, halte bus, kendaraan pribadi, angkutan umum, bahkan di lingkun ganrumah. Hal ini sudah menjadi pemandangan yang biasa dan jarang mendapat perhatian masyarakat, padahal perilaku tersebut berbahaya bagi remaja dan orang di sekitarnya. (Isa,dkk,2017).

Tidak hanya siswa SMA atau SMU, tetapi sudah merambah ke siswa SMP bahkan siswa SD. Kenyataan adanya siswa SD yang telah merokok tentu membuat keprihatinan, halini disebabkan karena rokok mempunyai sifat membuat orang kecanduan. Pada hal usia SD merupakan usia yang masih belia, mereka adalah anak- anak bangsa yang diharapkan kelak menjadi generasi penerus bangsa yang di pundak mereka nasib bangsa ini akan ditentukan. Jika sejak kecil mereka sudah diracuni oleh rokok, maka hal ini akan berpengaruh tidak hanya pada fisik mereka tetapi juga mental mereka. Jika anak-anak sudah kecanduan rokok sejak kecil maka akan lebih sulit untuk dihentikan. Oleh karena itu perlu dilakukan upaya untuk menghentikan kebiasaan ini pada anak SD yang sudah pernah merokok dan mencegah terjadinya kebiasaan merokok pada siswa yang belum pernah merokok. (Ambarwati \& dkk,2014)

Berdasarkan hasil penelitian Alamsyah \& Nopianto (2017) didapatkan informasi ada hubungan bermakna antara iklan rokok dengan perilaku merokok Siswa laki-laki kelas X dan XI di SMK Negeri 5 Pekanbaru yang tertarik iklan rokok beresiko 4,9 kali berperilaku merokok dibandingkan siswa laki-laki kelas X dan XI di SMK Negeri 5 Pekanbaru.

Berdasarkan hasil penelitian Alamsyah, \& Susanti (2017), didapatkan informasi bahwa ada hubungan antara keluarga yang merokok dengan perilaku merokok pada siswa/i SMPN 33 Kota Pekanbaru. Siswa/i yang memiliki keluarga yang merokok maka akan berisiko 2,4 kali untuk merokok.

Sekolah dasar negeri 004 Desa Domo merupakan salah satu sekolah yang yang berada di kecamatan Kampar Kiri Kabupaten Kampar tepat nya pada Desa Domo, dengan jumlah siswa pada tahun ajaran 2017/2018 dengan jumlah siswa siswi sebanyak 179 orang. SD 004 Desa Domo Kecamatan kampar Kiri Kabupaten Kampar Domo sudah terekditasi A, SD 002 dengan jumlah siswa pada tahun ajaran 2017/2018 dengan jumlah siswa siswi sebanyak 188 orang, sedangakan SD 011 Kuntu dengan jumlah siswa pada tahun ajaran 2017/2018 dengan jumlah siswa siswi sebanyak 128 orang. Berdasarkan obnservasi dan survei awal yang dilakukan peneliti, disekolah SDN 004 Desa Domo 
sering terjadi kasus perilaku merokok pada siswa laki laki, perilaku tersebut terjadi saat berada diluar lingkungan sekolah. Hasil dari survei awal dan wawancara terhadap 15 siswa laki-laki kelas IV, V, dan VI, 9 orang di antaranya pernah merokok setiap hari ataupun kadang-kadang. Menurut siswa SD keinginan mereka muncul karena rasa penasaran melihat anggota keluarga yang merokok (ayah, abang), saat memlihat iklan rokok di televisi dan media cetak lainnya, dan karena saat melihat teman sebaya nya merokok. Disini mereka di kasih uang jajan sama orang tua mereka untuk kesekolah ,ada yang di kasih sepuluh ribuh,delapan ribu hal ini tergantung dengan perekonomian keluarganya.

Keinginan dari rasa penasaran ini hingga akhirnya menyisihkan uang jajan mereka untuk membelih rokok 1 bantang atau 2 batang untuk di hisap sendiri maupun di hisap berkelompok di tempat yang mereka anggap aman seperti, dirumah kosong, dalam perkebunan dan ada pulah yang merokok di tepi sungai, dan mereka mengatakan tidak pernah merokok di perkarangan sekolah, karena banyaknya warung-warung yang mejual berbagai merek rokok membuat mereka dengan mudahnya membeli rokok. Karena masih rendahnya pengawasan dari orang tua membuat mereka mengulangi kembali tindankan tersebut, hasil wawancara dari salah satu guru, pihak sekolah tidak dapat mengawasi siswanya jika berada di luar lingkup sekolah, sekolah hanya memberi sanksi kepada siswa yang merokok dipanggil kekantor untuk diberikan masukan masukan supaya tidak mengulangi perbuatannya lagi. Berdasarka permasalah tersebut peneliti sangat tertarik melakukan penelitian megenai Perilaku Merokok pada siswa Sekolah Dasar (SD) di Kecamatan Kampar Kiri Kabupaten Kampar.

\section{METODE}

Penelitian ini bersifat Analitik kuantitatif observasional dengan desain
Cross Sectional dilakukan di SD Negeri 004 Desa Domo, SD Negeri 002 Kuntu dan SD Negeri 011 Kuntu Kecamatan Kampar Kiri Kabupaten Kampar pada bulan JanuariMaret Tahun 2018. Populasi dalam penelitian ini adalah seluruh siswa laki-laki dari kelas IV, V, VI pada 3 SD yang ada di Kecamatan Kampar Kiri Kabupaten Kampar yaitu siswa SDN 004 Desa Domo dengan jumlah 35 siswa, siswa SD 002 Kuntu dengan jumlah 45 siswa dan siswa SD 011 Kuntu dengan jumlah 20 siswa dengan menggunakan kriterian Inklusi dan ekslusi deng jumlah sampel keseluruhan adalah 100 sampel. Tenik pengambilan sampel pada penelitian ini ialah mengunakan teknik total sampling. Analisis data yang di gunakan adalah Analisis Univariat dan Bivariat dengan uji chi square.

\section{HASIL}

\section{Karakteristik Responden}

\section{Umur}

\begin{tabular}{llll} 
Tabel & $\mathbf{1}$ Distribusi & \multicolumn{2}{c}{ Frekuensi } \\
Berdasarkan Umur Siswa & $\begin{array}{l}\text { Responden } \\
\text { Kecamatan Kampar Kiri Kabupaten } \\
\text { Kampar }\end{array}$ \\
\hline No. & Umur & F & Presentase \\
\hline 1. & $5-10$ tahun & 55 & 58,5 \\
\hline 2. & $10-15$ tahun & 39 & 41,5 \\
& Total & & $\mathbf{1 0 0 . 0}$ \\
\hline
\end{tabular}

Berdasarkan Tabel 1 dapat di lihat dari 94 responden pada penelitian ini didapatkan bahwa sebagian besar responden dengan umur 5-10 tahun sebanyak 55 orang $(58,5 \%)$.

\section{Analisis Univariat}

Tabel 2 Analisis Univariat

\begin{tabular}{llcc}
\hline No. & Variabel Uji & Frekuensi & Persentase(\%) \\
\hline 1. & Perilaku & & \\
& merokok & & \\
& 1. ya & 57 & 60.6 \\
& 2. Tidak & 37 & 39,4 \\
\hline & Jumlah & 94 & 100.0 \\
\hline 2. & Pengetahuan & & \\
\hline
\end{tabular}




\begin{tabular}{|c|c|c|c|}
\hline & Rokok & & \\
\hline & 1. Rendah & 27 & 28.7 \\
\hline & 2. Tinggi & 67 & 71.3 \\
\hline & Jumlah & 94 & 100.0 \\
\hline 3. & Sikap & & \\
\hline & 1. negatif & 29 & 30.9 \\
\hline & 2. positif & 65 & 69.1 \\
\hline & Jumlah & 94 & 100.0 \\
\hline 4. & Iklan Rokok & & \\
\hline & 1. terpapar & 81 & 86.2 \\
\hline & $\begin{array}{ll}\text { 2. } & \text { tidak } \\
& \text { terpapar } \\
\end{array}$ & 13 & 13.2 \\
\hline & Jumlah & 94 & 100.0 \\
\hline 5. & Teman & & \\
\hline & Perokok & & \\
\hline & 1. terpapar & 67 & 71.3 \\
\hline & $\begin{array}{ll}\text { 2. } & \text { tidak } \\
\text { terpapar }\end{array}$ & 27 & 28.7 \\
\hline & Jumlah & 94 & 100.0 \\
\hline 6 & Keluarga & & \\
\hline & Perokok & & \\
\hline & 1. ada & 67 & 71,3 \\
\hline & 2. tidak & 27 & 28,7 \\
\hline & Jumlah & 94 & 100.0 \\
\hline 7 & Uang Jajan & & \\
\hline & 1. ada & 54 & 57.4 \\
\hline & 2. tidak & 40 & 4.6 \\
\hline & Jumlah & 94 & 100.0 \\
\hline
\end{tabular}

Berdasarkan Tabel 2 di atas, diketahui bahwa siswa yang berperilaku merokok berjumlah 57 orang $(60.6 \%)$, berpengetahuan rendah tentang rokok berjumlah 27 orang (28.7\%), sikap negatif terhadap rokok berjumlah 29 orang $(30.9 \%)$, terpapar iklan rokok berjumlah 81 orang $(86,2 \%)$, terpapar teman merokok berjumlah 67 orang $(71,3 \%)$, keluarga yang merokok berjumlah 67 orang $(71,3 \%)$, serta uang jajan untuk membeli rokok berjumlah 54 orang $(57.4 \%)$.

\section{Analisis Bivariat}

Hasil uji bivariat terhadap 6 variabel yang berhubungan dengan perilaku merokok pada siswa SD 004, SD 002, SD 011 yaitu pengetahuan, sikap, iklan rokok, teman perokok, keluarga perokok dan uang jajan. Seperti pada Tabel 3 sampai dengan Tabel 8.

\section{Hubungan Pengetahuan Rokok Terhadap Perilaku Merokok}

Tabel 3 Hubungan Pengetahuan terhadap Perilaku Merokok Pada Siswa Di SD. Negeri Kecamatan Kampar Kiri Kabupaten Kampar

\begin{tabular}{|c|c|c|c|c|c|c|c|c|}
\hline \multirow{3}{*}{ Pengetahuan } & \multicolumn{4}{|c|}{ Perilaku Merokok } & \multirow{2}{*}{\multicolumn{2}{|c|}{ Total }} & \multirow{3}{*}{$P$ Value } & \multirow[t]{3}{*}{ POR 95\% C.I } \\
\hline & \multicolumn{2}{|c|}{ Ya } & \multicolumn{2}{|c|}{ Tidak } & & & & \\
\hline & $\mathbf{n}$ & $\%$ & $\mathbf{n}$ & $\%$ & $\mathbf{n}$ & $\%$ & & \\
\hline Rendah & 22 & 23,4 & 5 & 5,3 & 27 & 28,7 & 0,017 & $\begin{array}{c}4,023 \\
(1,362-11,881)\end{array}$ \\
\hline Tinggi & 35 & 37,2 & 32 & 34,0 & 67 & 71,3 & & \\
\hline Jumlah & 57 & 60,6 & 37 & 39,4 & 94 & 100,0 & & \\
\hline
\end{tabular}

Berdasarkan Tabel 3, dari 27 responden $(28,7)$ berpengetahuan rendah berperilaku merokok sebanyak $22(23,4 \%)$ sedangkan dari 67 responden $(71,3 \%)$ berpengetahuan tinggi berperilaku merokok sebayak 35 $(37,2 \%)$. Hasil uji statistik $p=0,017$ (p value $<0,05)$ maka dapat disimpulkan ada hubungan signifikan antara pengetahuan dengan perilaku merokok. Dari hasil analisis diperoleh $\mathrm{POR}=4,023$ artinya responden berpengetahuan rendah mempunyai risiko 4 kali melakukan perilaku merokok dibandingkan dengan responden yang berpengetahuan tinggi. 
Hubungan Sikap Terhadap Perilaku Merokok

Tabel 4. Hubungan SikapTerhadap Perilaku Merokok Pada Siswa Di SD Negeri Kuntu Kecamatan Kampar Kiri Kabupaten Kampar

\begin{tabular}{|c|c|c|c|c|c|c|c|c|}
\hline \multirow{3}{*}{ Sikap } & \multicolumn{4}{|c|}{ Perilaku Merokok } & \multirow{2}{*}{\multicolumn{2}{|c|}{ Total }} & \multirow{3}{*}{$P$ Value } & \multirow[t]{3}{*}{ POR 95\% C.I } \\
\hline & \multicolumn{2}{|c|}{ Ya } & \multicolumn{2}{|c|}{ Tidak } & & & & \\
\hline & $\mathbf{n}$ & $\%$ & $\mathbf{n}$ & $\%$ & $\mathbf{n}$ & $\%$ & & \\
\hline Negatif & 27 & 28,7 & 2 & 2,1 & 29 & 30,9 & 0,000 & $\begin{array}{c}15,750 \\
(3,456-71,86)\end{array}$ \\
\hline Positif & 30 & 31,9 & 35 & 37,2 & 65 & 69,1 & & \\
\hline Jumlah & 57 & 60,6 & 37 & 39,4 & 94 & 100,0 & & \\
\hline
\end{tabular}

Berdasarkan Tabel 4, dari 29 responden $(30,9 \%)$ bersikap negatif berperilaku merokok sebanyak $27(28,7 \%)$. Sedangkan dari $65(69,1 \%)$ responden yang bersikap positif berperilaku merokok sebanyak 30 responden $(31,9 \%)$. Hasil uji stastistik di peroleh $\mathrm{p}=0,000$ ( $p$ value $<0,05)$ maka dapat disimpulkan ada hubungan signifikan antara sikap dengan perilaku merokok. Dari hasil analisis diperoleh POR $=15,750$ artinya responden yang bersikap negatif mempunyai risiko $15 \mathrm{kali}$ melakukan perilaku merokok dibandingkan dengan responden yang bersikap positif.

Hubungan Iklan Rokok Terhadap Perilaku Merokok

Tabel 5. Hubungan Iklan Rokok Terhadap Perilaku Merokok Pada Siswa Di SD. Negeri Kecamatan Kampar Kiri Kabupaten Kampar

\begin{tabular}{|c|c|c|c|c|c|c|c|c|}
\hline \multirow{3}{*}{ Iklan Rokok } & \multicolumn{4}{|c|}{ Perilaku Merokok } & \multirow{2}{*}{\multicolumn{2}{|c|}{ Total }} & \multirow[t]{3}{*}{$P$ Value } & \multirow{3}{*}{ POR 95\% C.I } \\
\hline & \multicolumn{2}{|c|}{ Ya } & \multicolumn{2}{|c|}{ Tidak } & & & & \\
\hline & $\mathbf{N}$ & $\%$ & $\mathbf{n}$ & $\%$ & $\mathbf{n}$ & $\%$ & & \\
\hline Terpapar & 53 & 56,4 & 28 & 29,8 & 81 & 86,2 & 0,039 & $\begin{array}{c}4,259 \\
(1204-15.070)\end{array}$ \\
\hline Tidak Terpapar & 4 & 4,3 & 9 & 9,6 & 13 & 13,8 & & \\
\hline Jumlah & 57 & 60,6 & 37 & 39,4 & 94 & 100,0 & & \\
\hline
\end{tabular}

Berdasarkan Tabel 5, dari 81 responden $(86,2 \%)$ dengan berperilaku merokok terpapar iklan rokok sebanyak $53(56,4 \%)$. Sedangkan dari $13(13,8 \%)$ responden yang berperilaku merokok tidak terpapar sebanyak 4 responden $(4,3 \%)$. Hasil uji stastistik di peroleh $\mathrm{p}=0,039$ ( $p$ value $<$ $0,05)$ maka dapat disimpulkan ada hubungan signifikan antara iklan rokok dengan perilaku merokok pada responden. Dari hasil analisis diperoleh POR $=4,259$ artinya responden yang terpapar iklan rokok mempunyai risiko 4 kali melakukan perilaku merokok dibandingkan dengan responden yang tidak terpapar iklan rokok.

Hubungan Teman Perokok Terhadap Perilaku Merokok

Tabel 6. Hubungan Teman perokok Terhadap Perilaku Merokok Pada Siswa

Di SD Negeri Kecamatan Kampar Kiri Kabupaten Kampar

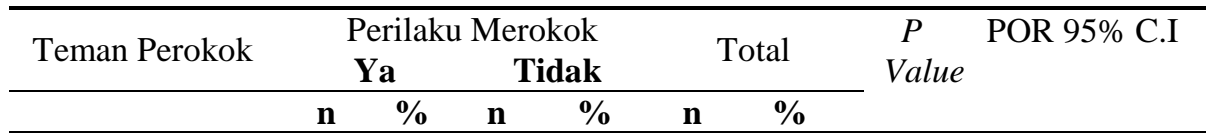




\begin{tabular}{ccccccccc}
\hline Ada & 49 & 52,1 & 18 & 19,1 & 67 & 71,3 & 0,000 & $\begin{array}{c}6,465 \\
(2,410- \\
17,348)\end{array}$ \\
Tidak Ada & 8 & 8,5 & 19 & 20,2 & 27 & 28,7 & & \\
\hline Jumlah & 57 & 60,6 & 37 & 39,4 & 94 & 100,0 & & \\
\hline
\end{tabular}

Berdasarkan Tabel 6, dari 67 responden $(71,3 \%)$ dengan berperilaku merokok ada teman perokok sebanyak $49 \quad(52,1 \%)$. Sedangkan dari $27(28,7 \%)$ responden yang berperilaku merokok tidak ada sebanyak 8 responden $(8,5 \%)$. Hasil uji stastistik di peroleh $\mathrm{p}=0,000$ ( $p$ value $<0,05$ ) maka dapat disimpulkan ada hubungan signifikan antara teman perokok dengan perilaku merokok dengan perilaku merokok pada responden. Dari hasil analisis diperoleh $\mathrm{POR}=6,465$ artinya responden yang ada teman perokok mempunyai risiko 6 kali melakukan perilaku merokok dibandingkan dengan responden yang tidak ada teman perokok.

\section{Hubungan Keluarga Perokok Terhadap Perilaku Merokok}

Tabel 7. Hubungan Keluarga perokok Terhadap Perilaku Merokok Pada Siswa Di SD Negeri Kecamatan Kampar Kiri Kabupaten Kampar

\begin{tabular}{|c|c|c|c|c|c|c|c|c|}
\hline \multirow{3}{*}{ Keluarga perokok } & \multicolumn{4}{|c|}{ Perilaku Merokok } & \multirow{2}{*}{\multicolumn{2}{|c|}{ Total }} & \multirow{3}{*}{ P Value } & \multirow[t]{3}{*}{ POR 95\% C.I } \\
\hline & \multicolumn{2}{|c|}{ Ya } & \multicolumn{2}{|c|}{ Tidak } & & & & \\
\hline & $\mathbf{n}$ & $\%$ & $\mathbf{n}$ & $\%$ & $\mathbf{n}$ & $\%$ & & \\
\hline Ada & 49 & 52,1 & 18 & 19,1 & 67 & 71,3 & 0,000 & $\begin{array}{c}6,465 \\
(2,410-17,348)\end{array}$ \\
\hline Tidak Ada & 8 & 8,5 & 19 & 20,2 & 27 & 28,7 & & \\
\hline Jumlah & 57 & 60,6 & 37 & 39,4 & 94 & 100,0 & & \\
\hline
\end{tabular}

Berdasarkan Tabel 7, dari 67 responden $(71,3 \%)$ dengan keluarga perokok ada sebanyak $49(52,1 \%)$. Sedangkan dari 27 $(28,7 \%)$ responden yang tidak ada keluarga perokok sebanyak 8 responden $(8,5 \%)$. Hasil uji stastistik di peroleh $\mathrm{p}=0,000(p$ value $<0,05)$ maka dapat disimpulkan ada hubungan signifikan antara keluarga perokok dengan perilaku merokok pada siswa. Dari hasil analisis diperoleh POR = 6,465 artinya responden yang ada keluarga merokok mempunyai risiko 6 kali melakukan perilaku merokok dibandingkan dengan responden yang tidak ada keluarga merokok.

\section{Hubungan Uang Jajan Terhadap Perilaku Merokok}

Tabel 8. Hubungan Uang JajanTerhadap Perilaku Merokok Pada Siswa Di SD Negeri Kecamatan Kampar Kiri Kabupaten Kampar

\begin{tabular}{ccccccccc}
\hline \multirow{2}{*}{ Uang Jajan } & \multicolumn{4}{c}{ Perilaku Merokok } & \multicolumn{2}{c}{ Total } & \multirow{2}{*}{ P Value } & POR 95\% C.I \\
& Ya & $\%$ & Tidak & \% & n & $\%$ & & \\
\hline Ada & 54 & 57,4 & 0 & 0,0 & 54 & 57,4 & 0,000 & 13,333 \\
Tidak & 3 & 3,2 & 37 & 39,4 & 40 & 42,6 & & \\
\hline Jumlah & 57 & 60,6 & 37 & 39,4 & 94 & 100,0 & & \\
\hline
\end{tabular}

Berdasarkan Tabel 8, dari 54 responden $(57,4 \%)$ ada uang jajan sebanyak 54 $(57,4 \%)$. Sedangkan dari $40 \quad(42,6 \%)$ responden yang tidak ada uang jajan sebanyak 3 responden $(3,2 \%)$. Hasil uji stastistik di peroleh $\mathrm{p}=0,000$ ( $p$ value < $0,05)$ maka dapat disimpulkan ada hubungan signifikan antara uang jajan dengan dengan perilaku merokok pada siswa. Dari hasil analisis diperoleh POR = 13,333 artinya responden yang ada uang 
jajan mempunyai risiko 13 kali melakukan perilaku merokok dibandingkan dengan responden yang tidak ada uang jajan.

tahu saja, tetapi belum mengetahui secara rinci bahwa merokok benar benar dapat menimbulkan masalah kesehatan.

\section{Sikap}

Berdasarkan nilai $\mathrm{P}=0,000$ ( $p$ value $\leq$ $0,05)$, ada terdapat hubungan signifikan antara sikap dengan perilaku merokok di SD 004 Domo,SD 002 Kuntu dan SD 011 Kuntu Kecamatan Kampar Kiri Kabupaten Kampar. Hasil penelitian ini sejalan dengan penelitian Alamsyah A, Nopianto (2017), menyatakan terdapat hubungan yang bermakna antara sikap negatif tentang rokok terhadap perilaku merokok.

Sikap merupan konsep yang sangat penting komponen sosio-psikologis, kerena merupakan kecenderungan bertindak dan berpesepsi. Sikap belum merupakan suatu tindakan atau aktifitas akan tetapi merupakan predisposisi tindakan suatu perilaku Notoatmodjo (2010). Sikap merupakan reaksi atau respon yang masih tertutup dari seseorang terhadap suatu stimulus atau objek (Achmadi, 2014).

Berdasarkan analisis dari peneliti, dapat disimpulkan bahwa sikap merokok pada anak SD hanya sekedar rasa ingin cobacoba yang mereka lakukan tampa mengetahui efek bahaya merokok tersebut, rasa ingin coba coba tersebut timbul karena faktor lingkungan seperti melihat keluarganya ada yang merokok, ajakan teman sebaya untuk merokok bersama bersama di tempat tempat yang mereka angap nyaman dan jauh dari pantauan orang tuanya dan karena banyaknya warungwarung yang menjual rokok tersebut yang membuat mereka dengan muda untuk membeli rokok tersebut. 


\section{Iklan rokok}

Hasil uji stastistik di peroleh $\mathrm{p}=0,030$ ( $p$ value $<0,05$ ) ada hubungan antara iklan dengan perilaku merokok pada siswa di SD 004 Domo, SD 002 Kuntu dan SD 011 Kuntu Kecamatan Kampar Kiri Kabupaten Kampar.

Hasil penelitian ini sejalan dengan Faridah, F. (2017). yang menyatakan terdapat hubungan iklan rokok dengan perilaku merokok pada remaja kelas smk "x" Surakarta tahun 2017. Iklan rokok diberbagai tempat dan media masa yang saat ini makin merajajela sangat menarik bagi parah remaja.

Berdasarkan analisis peneliti dapat disimpulkan bahwa ada hubungan antara iklan rokok dengan perilaku merokok pada remaja disebabkan karena pada usia remaja kurang peduli dengan media, mereka lebih banyak mendapatkan imformasi dari teman sebayanya, padahal informasi yang mereka peroleh salah, informasih dari teman yang mereka dapatkan bahwa rokok itu membuat mereka lebih terlihat macho, padahal secara teori merokok membahayakan kesehatan tubuh. Iklan rokok dikemas semenarik mungkin dengan mengakat tema perteman, persahabatan maupun kebersamaan. Iklan rokok dibuat dengan sangat atraktif dan kreatif menyentuh sisi psikologis yang menunjukan citra berani, macho tren, keren, kebersamaan, santai, optimis, jantan, penuh petualangan serta berbagai hal yang membanggakan dan mewakili suara hati anak mudah dan remaja. Apalagi dizaman sekarang anak remaja dengan mudanya melihat berbagai banyaknya iklan rokok ditelevisi maupun media-media lain seperti poster-poster yang di ditempatkan di tempat yang strategis (tepi-tepi jalan) dan berbagai macam media lain.

\section{Teman perokok}

Berdasarkan nilai $\mathrm{p}=0,000$ ( $p$ value $\leq$ $0,05)$, ada hubungan signifikan antara teman perokok dengan perilaku merokok di SD 004 Domo,SD 002 Kuntu dan SD 011
Kuntu Kecamatan Kampar Kiri Kabupaten Kampar.

Hasil penelitian ini sejalan dengan penelitian Yulviana (2015), yang menyebutkan bahwa terdapat hubungan yang signifikan antara teman perokok dengan perilaku merokok pada remaja putra kelas X dan XI di SMAN 6 Pekanbaru. Di usia remaja, anak akan mempunyai banyak teman perokok dengan latar belakang sosial, ekonomi, dan budaya yang beragam. Di antara sekian banyak temannya, ada yang bisa membawa pengaruh positif dan sebaliknya membawa pengaruh buruk. Semakin banyak remaja yang merokok, maka semakin besar kemungkinan teman temannya adalah perokok pada usia 12-13 tahun tekanan dari teman sebaya dan pengaruh lain makin sulit dilawan jika teman teman sebaya merokok, maka remaja akan mudah tergoda untuk bergabung dengan teman teman perokok.

Adapun analisis dari peneliti, dapat disimpulkan bahwa ada hubungan antara teman perokok dengan perilaku merokok,karena dalam keseharian responden banyak bergaul dengan teman temannya, baik disekolah maupun diluar sekolah dan untuk dapat diterima dan bergabung menjadi anggota kelompok teman, seorang anak harus bisa menjalankan peran dan tingkah laku sesuai dengan harapan dan tuntutan kelompok sebaya dan dan perilaku merokok yang dilakukan oleh anak mungkin merupakan salah satu pengaruh buruk yang di dapat oleh teman temannya, sehabis pulang sekolah mereka bermain ketempat tempat yang mereka anggap bisa santai bisa bermain bahkan membeli rokok di warung warung melakukan perilaku merokok bersama sama, seperti di tepi sungai dirumah rumah kosong dan ditempat tempat yang mereka angap nyaman. Di masa ini remaja rentan terpengaruh oleh pergaulan yang sudah mulai terbentuk kelompok kelompok pertemanan (geng) yang juluki remaja zaman sekarang. Karena yang tidak memiliki geng menurut mereka kurang gaul 
sehingga dimasa inilah banyak melakukan hal-hal baru yang membuat mereka penasaran.

\section{Keluarga perokok}

Berdasarkan nilai $\mathrm{P}=0,000$ ( $p$ value $<$ $0,05)$, ada hubungan antara keluarga perokok dengan perilaku merokok pada siswa di SD 004 Domo, SD 002 Kuntu dan SD 011 Kuntu Kecamatan Kampar Kiri Kabupaten Kampar.

Dukungan keluarga dari keluarga tedekat penting bagi seseorang dalam betindak dan mengambil keputusan. Keluarga mempunyai peran yang sangat strategis membentuk sikap remaja. Keluarga merupakan sekolah dan tempat pembelajaran petama seorang remaja. Orang tua merupakan teladan bagi anak anak, interaksi yang mendalam antara orang tua dan anak, melahirkan karakter yang mirip, orang tua merupakan model bagi seorang anak(remaja). Orang tua berperan penting dalam menginisiasi remaja merokok. Orang tua merokok dianggap sebagian bentuk legitimidasi merokok bagi anak anak mereka (Alamsyah \& Susanti, 2017).

Hasil penelitian ini sejalan dengan penelitian Isa dkk (2017), ada hubungan yang bermakna antara peran orang tua dan saudara dengan perilaku merokok siswa SMP Negeri 9 Kendari.

Adapun analisis dari peneliti, dapat disimpulkan bahwa ada hubungan keluarga merokok dengan perilaku merokok, karena keluarga sangat berperan dalam membentuk sikap dan kepribadian seorang anak, anak cenderung lebih meniruh perilaku yang dilakukan oleh orang tua atau keluarganya baik itu tindakan positif atau negatif karena keluarga merupakan model bagi seorang anak. Maka secara umum wajar jika yang memiliki orang tua atau keluarga yang merokok cenderung berperilaku merokok juga. Hal ini sesuai dengan perkembangan psikososial remaja yang mengatakan bahwa remaja sering kali berusaha meniru apa yang dilakukan oleh orangtuanya. Seorang anak yang dilahirkan dalam keluarga perokok lebih cenderung meniru kebiasaan merokok kedua orangtuanya, hal ini bisa diawali dengan mereka sebagai perokok pasif yang selalu berada dilingkungan keluarga perokok, mereka turut juga menghirup asap rokok. Seorang anak yang berada dalam kandungan ibunya yang mempunyai ayah atau ibu seorang perokok, dimana pada fase janin ia sudah terpapar asap rokok atau nikptin yang disalurkan kepadanya melalui placenta maka pada saat ia memasuki masa remaja hingga dewasa nanti akan mempunyai kecen derungan yang besar untuk merokok.

\section{Uang jajan}

Berdasarkan nilai $\mathrm{p}=0,000$ ( $p$ value $\leq$ $0,05)$, ada hubungan signifikan antara uang jajan dengan perilaku merokokdi SD 004 Domo,SD 002 Kuntu dan SD 011 Kuntu Kecamatan Kampar Kiri Kabupaten Kampar

Sebagai ungkapan rasa kasih sayang terhadap putra putrinya terkdang orang tua memberikan fasilatas dan uang yang berlebihan. Hal itu disalah gunakan untuk memuaskan segalah ke inginan dirinya di antaranya merokok (Soetjiningsih, 2004). Perokok berat akan memilih merokok dari pada makan jika uang yang dimilikinya terbatas, jika uang yang diberikan orang tuanya berlebih, maka remaja sangat mudah untuk membeli rokok. Hal ini dikarenakan harga jual rokok di indonesia masih terjangkau untuk para remaja (Jaya, 2009).

Hasil penelitian ini sejalan dengan penelitian Alamsyah, Susanti (2017), yang menyebut bahwa terdapat hubungan antara uang saku lebih dengan perilaku merokok pada siswa siswa kelas 7 dan 8 SMPN 33 Kota Pekanbaru.

Adapun analis dari peneliti,dapat disimpulkan bahwa ada hubungan uang jajan dengan perilaku, karena uang jajan yang diberikan oleh orang tua yang berlebihan akan menimbulkan masalah yaitu remaja menjadi boros sehinga remaja cenderung tergoda dan merasa kecanduan dengan rokok karena harga rokok yang 
tidak mahal, banyaknya warung warung jualan rokok di desa tersebut hal ini memudahkan remaja membeli rokok ditambah lagi dengan harga rata rata harga satu batang rokok mulai dari Rp1000Rp1500 dengan hal ini remaja yang dikasih uang jajan Rp5000 dalam satu hari bisa menyisahakan uang jajan yang diberikan orang tuanya untuk membeli rokok untuk merokok bersama teman temannya di tempat yang mereka anggap nyaman seperti perkebunan sawit, perkebunan karet, dan rumah rumah kosong.

\section{KESIMPULAN}

Berdasarkan hasil penelitian dan pembahasan tentang perilaku merokok siswa SD. Negeri Kecamatan Kampar Kiri Kabupaten Kampar mayoritas berperilaku merokok sebanyak 57 orang $(60,6 \%)$, tidak berperilaku merokok sebanyak 37 orang $(39,4 \%)$ pada umur 5-10 tahun sebanyak 55 orang $(58,5 \%)$, maka dapat di ambil kesimpulan sebagai berikut semua varibel berhubungan yaitu Pengetahuan, Sikap, Iklan Rokok, Teman Perokok, Keluarga Perokok da Uang jajan. Yang merupakan variabel yang paling dominan/berisiko dengan berperilaku merokok yaitu Sikap (P Value $=0,000)$, POR 15,750. Peneliti merekomendasi kepada pihak sekolah dan orang tua untuk memberikaan edukasih kepada anak-anak sekolah dasar supaya anak anak tidak terpengaruh oleh pengaruh pergaulan bebas seperti berperilaku merokok, disatu sisi kondisi anak masih labil jadi peran orang tua lebih di tingkatkan lagi seperti mengawasi dan meminitoring kegiatan anak selama sehari.

\section{DAFTAR PUSTAKA}

Achmadi ,U, F. (2014), kesehatan masyarat teori dan aplikasi, jakarta: RajaGrapindo Persada
Alamsyah, A \& Novianto (2017), Determinan perilaku merokok ada remaja. Journal Endurance 2(1) Februari 2017 (25-30)

Alamsyah, A, \& Susanti, N. (2017), Epidemiologi merokok pada siswa kelas 7 dan 8 SMPN 33 Kota Pekanbaru. Jurnal Photon Vol. 8 No, 1, Oktober 2017.

Ambarwati \& dkk (2014), media leaflet, video dan pengetahuan siswa SD tentang bahaya merokok. Jurnal Kesehatan Masyarakat. KEMAS 10 (1) (2014) $7-1 \mathrm{~F}$

Faridah, F. (2017). Analisis faktor-faktor penyebab perilaku merokok remaja di smk " $x$ " surakarta. Jurnal Kesehatan Masyarakat (eJournal), 3(3), 887-897

Isa,L,\&dkk (2017), hubungan tipe kepribadian, peran orang tua dan saudara,peran teman sebaya, dan peran iklan rokok dengan perilaku merokok pada siswa smp negeri 9 kendari tahun 2017, jurnal kesehatan masyarakat vol.2/NO.7/AGUSTUS 2017; ISSN 2502-731X

Jaya,M.(2009),Pembunuh berbahaya itu bernama rokok. Yogyakarta:riz`ma.

Notoadmodjo, S.(2010), Ilmu perilaku kesehatan,,Jakarta:Rineka Cipta

Notoadmodjo, S.(2011), Ilmu kesehatan masyarakat ilmu dan seni dasar,Jakarta:Rineka Cipta

Riskesdas, (2013), pokok pokok hasil riset kesehatan dasar provinsi Riau.

Soetjiningsih, 2004, Tumbuh kembang remaja dan permasalahannya (buku ajar)

Wulandari,S.(2017), Pengetahuan siswa remaja tentang bahaya rokok di SMPN 2 Rambah Hilir Kabupaten Rokan Hulu. Jurnal maternity and Neonatal Vol 2 No 2.

Yulviana,R. (2015), faktor-faktor yang berhubungan dengan kebiasaan merokok pada remaja putra kelas $X$ dan XI di SMAN 6 Pekanbaru. Vol 2 No 6, Mei 2015. 